\title{
Forecasting Design and Principal Dimension Decision in Ship Design Using Parent Design Approach for Folding Boat
}

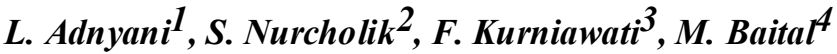 \\ ${ }^{1}$ Naval Architecture and Shipbuilding, Kalimantan Institute of Technology. Email:luhputria@itk.ac.id \\ ${ }^{2}$ Naval Architecture and Shipbuilding, Kalimantan Institute of Technology. Email:dlukha@itk.ac.id \\ ${ }^{3}$ Naval Architecture and Shipbuilding, Kalimantan Institute of Technology. Email:fiqih@itk.ac.id \\ ${ }^{4}$ Naval Architecture and Shipbuilding, Kalimantan Institute of Technology. Email: sawal.b@itk.ac.id
}

\begin{abstract}
In the Nawacita program of the Indonesia President, there is a spirit of accelerating the pace of economic growth in all areas, including tourism. In 2016, national income from the tourism sector rose to the fourth position under oil and gas, coal and palm oil. This program is followed up by areas that have great tourism potential, one of which is East Kalimantan. Most East Kalimantan area based on marine tourism, islands and rivers, it is necessary to create adequate facilities to attract more tourists as well as Bali such as in water sport facilities. One of the most famous water sport is kayaking in Sanur, Kuta, Benoa and others. Seeing the potential of marine tourism in East Kalimantan and the use of kayak already exist in Bali, it is necessary to design a kayak that can be utilized in tourist areas of East Kalimantan. The exist ing tourist areas in the East Kalimantan region have a long distance and isolated locations that require efficient luggage. Besides, the area has not supported tourism facilities and infrastructure needed by tourists. Therefore, the aim this research is to design a folding boar so that practical to be moved, light and easy for the owner to use it.
\end{abstract}

Keywords: folding boat, parent design approach, sister ship, stability

\begin{abstract}
Abstrak
Dalam program Nawacita Presiden RI, terkandung semangat percepatan laju pertumbuhan ekonomi di segala bidang, termasuk pariwisata. Pada tahun 2016, penghasilan devisa dari sektor pariwisata langsung naik ke posisi keempat di bawah minyak dan gas, batubara dan minyak kelapa sawit. Program nawacita ini ditindaklanjuti oleh daerah-daerah yang memiliki potensi pariwisata yang besar, salah satunya Kalimantan Timur. Kaltim memiliki cakupan daerah di Kalimantan Timur yang bertumpu pada pariwisata bahari, kepulauan dan sungai, maka perlu dibuat sebuah fasilitas dan sarana yang memadai untuk menarik wisatawan yang lebih banyak. Provinsi Bali yang sudah dari lama bertumpu pada sector pariwisata, memiliki banyak water sport yang menjadi incaran wisatawan khususnya wisatawan asing. Salah satu yang terkenal adalah olahraga kayak di Sanur, Kuta, Benoa dan lainnya. Melihat potensi wisata bahari di Kalimantan Timur dan pemanfaatan kayak yang sudah ramai di Bali, maka perlu dirancang sebuah kayak yang bisa dimanfaatkan di daerah wisata Kaltim. Daerah wisata yang ada di daerah Kalimantan Timur rata-rata memiliki jarak tempuh yang jauh dan lokasi yang terisolasi sehingga dibutuhkan barang bawaan yang efisien. Disamping itu daerah belum mendukung kegiatan pariwisata dengan tidak adanya fasilitas dan sarana prasarana yang dibutuhkan wisatawan. Oleh karena itu, dalam penelitian ini dicoba dirancang sebuah sampan (kayak) yang bisa dilipat sehingga praktis untuk dipindahkan, ringan dan mudah bagi si pemilik memakainya..
\end{abstract}

Kata Kunci: kapal lipat, parent design approach, sister ship, stability

\section{Introduction}

In national development, the tourism sector is one of the most important sectors to make national improvement. Tourism sector can increasing the economic activity of a region, encourage regional development, increase employments and introduce cultural values and natural products in the local area. Indonesia is one of the rich countries in natural beauty that has the potential to promote the development of Indonesian tourism. In Nawacita program of Indonesia President, there is a spirit of accelerating the pace of economic growth in all areas, including tourism. In 2016, national income from the tourism sector rose to the fourth position under oil and gas, coal and palm oil. This program is followed up by areas that have great tourism potential, such as East Kalimantan. East Kalimantan through East Kalimantan Provincial Regulation No. 14 of 2008 on the Regional Tourism 
Development Master Plan of East Kalimantan province intensify the tourism sector according to the condition of the region through sustainable economic development. And one of the plans is the determination of tourism development areas, 10 areas are created, 3 of them are marine tourism, coastal and river ecotourism.

Seeing the vast coverage area in East Kalimantan that is based on marine tourism, islands and rivers, it is necessary to create adequate facilities to attract more tourists. Bali Province which has long been based on the tourism sector, has a lot of water sports that became the target of tourists, especially foreign tourists. One of the most famous water sports are kayaking in Sanur, Kuta, Benoa and others. Seeing the potential of marine tourism in East Kalimantan and the use of kayak already exists in Bali, it is necessary to design a kayak that can be utilized in tourist areas of East Kalimantan. The existing tourist areas in the East Kalimantan region have a long distance and isolated locations that require efficient luggage. Besides, the area has not supported tourism activities in the absence of facilities and infrastructure are needed by tourists. Therefore, designed of kayak that can be folded so that it is practical to move, light and easy for the owner to use it, which is hereinafter called the folding boat.

The U.S. Navy has experimented with many approaches to design and build its ships. Using an existing design as the "parent" design, also referred to as "modified-repeat" design, is on its face an attractive option. Many acquisition executives, program managers and some ship design engineers believe that a design based on a parent has fewer technical risks than a new "clean sheet of paper" design and therefore the time and cost to design and build it will be reduced (Keane). In 1959, the concept of design spiral is introduced, which represents the sequential and iterative aspects of the process (Evans, 1959). Stages to do ship design were divided to 4 stages, starting from concept design, preliminary design, contract design and detail design (Ventura, 1997). Data to which a naval architect may want to refer can take many forms, but the principal items which he should collect are (Watson, 1997):

- data on ship dimensions and dimensional ratios

- data on ship's lines, with block coefficient and LCB position, etc. (see

- data on powering

- data on general arrangements

- data on steel-weight, outfit weights and machinery

- data on areas and volumes

- data on the many rules applicable to ships

- data on the many different items that make up outfit with notes on their capabilities, weights and the services they require

- cost data of all sorts

\section{Methods}

Parent design approach is one method in ship designing by comparison, that means sister ship has the same characteristics with ship to be designed. In this case the designer already has the same ship and proved to have good performance (technically and operationally). Advantages in the parent design approach is to design a ship faster, because there is a sister ship modify only for proven ship performance (stability, motion, resistance), and confidence. Meanwhile, the weakness is a ship designed to be difficult to market if there is a new technology that is being entered (competition between products). The design process is a continuous and repeatedly process to produce a design that matches what is desired. In the new ship development process design there are several stages of design, among others (Taggart, 1980). Four stages of the design can be described in a spiral design (Evans, 1959) which is an iteration process starting from the requirements given by the ship owner to make detail design ready for use in the production process.

The research flow diagram is shown in Figure 2 starting from the literature study, planning, procurement, design until making process of the folding boat. 


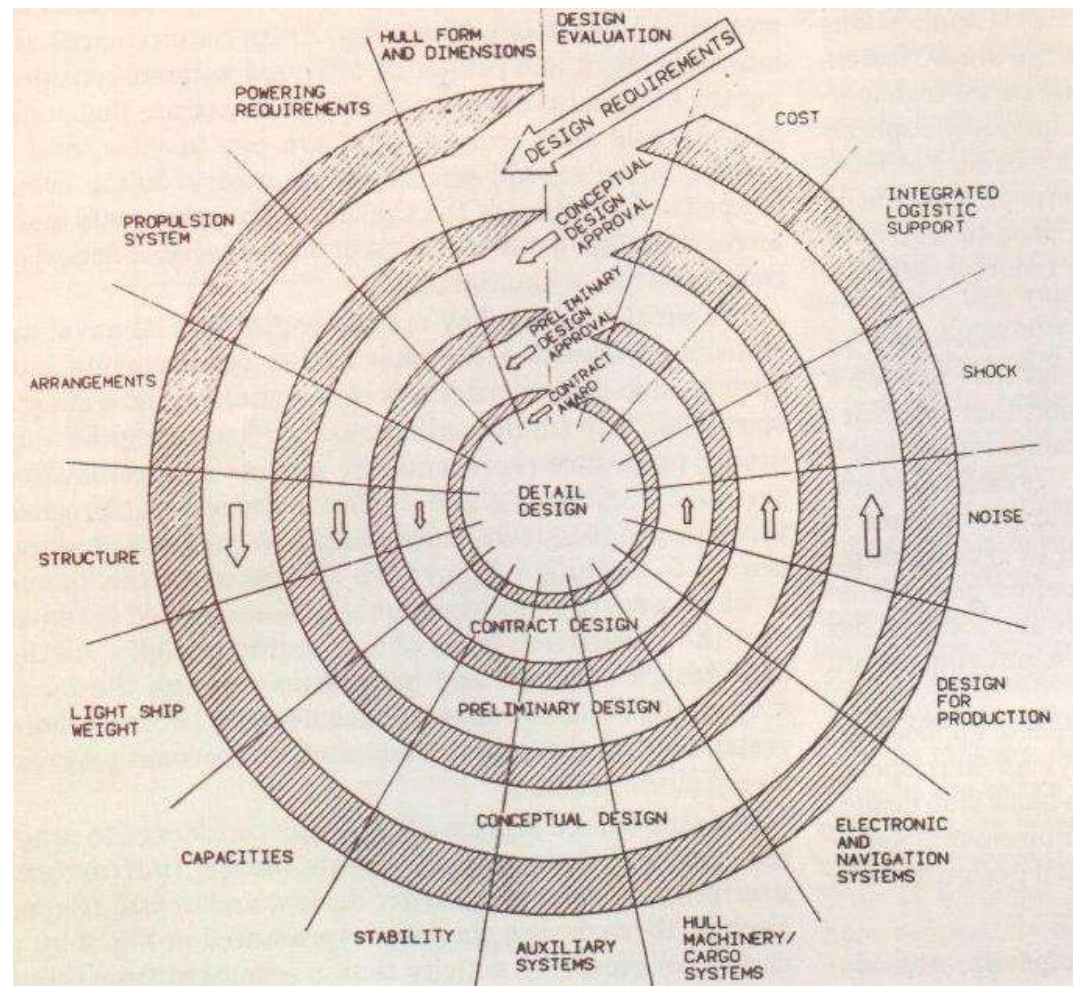

Figure 1. Basic Design Spiral Evans [2]

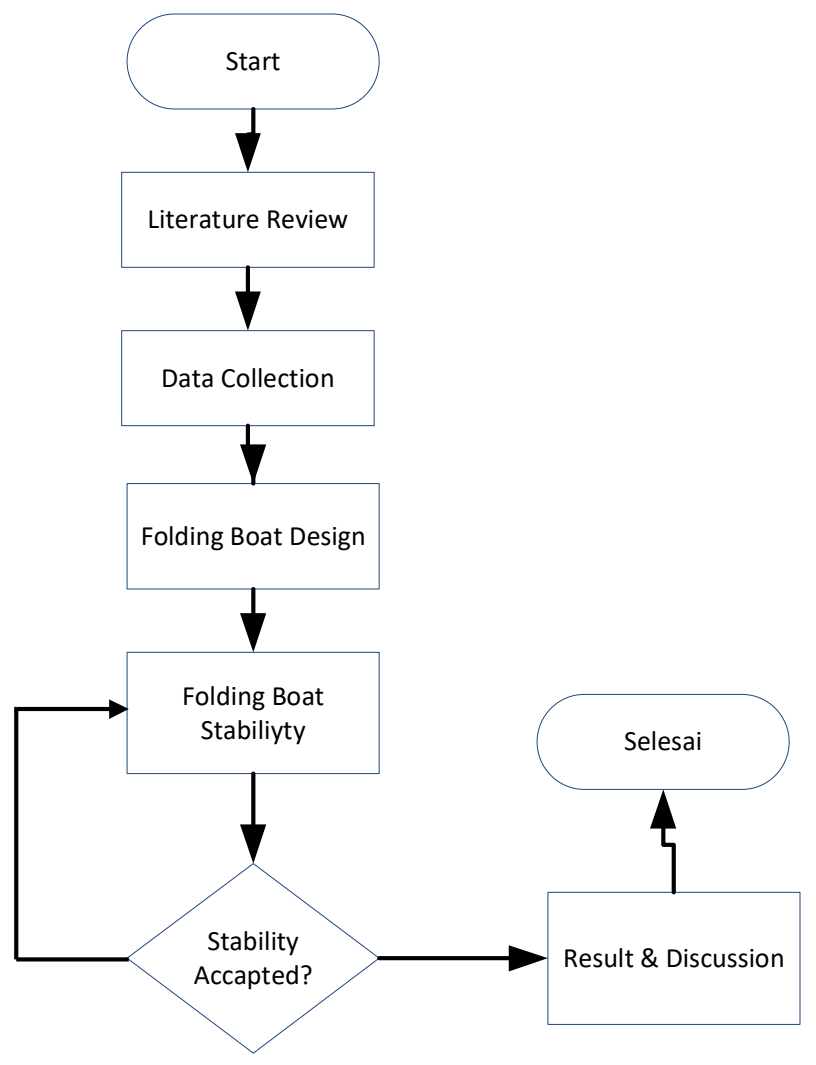

Figure 2. Flowcharts 


\subsection{Data}

The main measure in this paper tis determined by Parent method Design Approach. This method uses a comparative ship design already sailing well as the main reference. Selection of the comparison vessel as well considering the stability of existing folding boat, so that the convenience aspect also not to be missed for consideration. The output of this design method is get a new design from the sister ship. In this research, which is used as a comparative ship is the folding boat created by the Belgium Company "ONAK". This folding boat suitable for use in relatively static waters for those who love outdoor sports this ship can easily store and carry for more style designs. Material for ONAK is polymer polypropylene, thickness: $4.2 \mathrm{~mm}$, Weight: $32 \mathrm{~kg}$. Loading Capacity: $500 \mathrm{~kg}$.

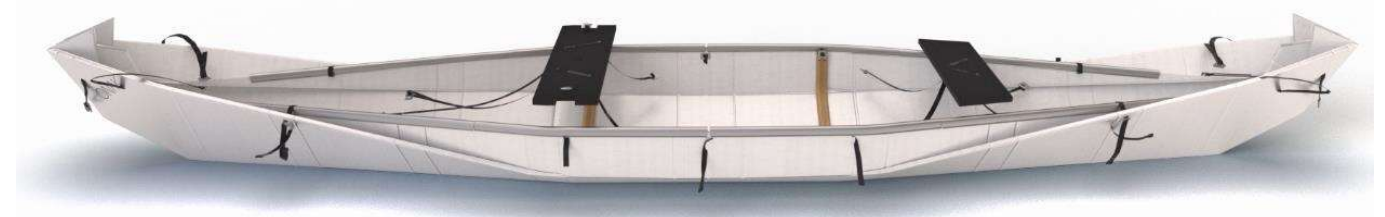

Figure 3. ONAK Created by Belgium Company [6]

Specification of ONAK Canoe:

- $465 \mathrm{~cm}(183$ ”) x $85 \mathrm{~cm}(33.5 ")$

- Capacity $200 \mathrm{~kg}(441 \mathrm{lbs})$ to $250 \mathrm{~kg}(551 \mathrm{lbs})$

Case on wheels:

- $40 \mathrm{~cm}\left(16^{\prime \prime}\right)$ x $120 \mathrm{~cm}\left(48^{\prime \prime}\right)$ x $25 \mathrm{~cm}(10 ”)$

- Weight $17 \mathrm{~kg}(37 \mathrm{lbs})$

\section{Result and Discussion}

The steps to determine the main size of the vessel by method Parent Design Approach is actually very simple and it is one of the advantages of this method that can speed up the design process. Using an existing design as the parent design is on its face an attractive option. The anticipated advantages are many:

- Can avoid the scrutiny that a new clean sheet design receives from the many Department of Defense (DoD) offices, usually in the form of additional approval milestones

- Can argue that design and construction costs will be less

- Can rationalize that construction can start earlier in the acquisition process

- Can circumvent the additional requirements that the Navy's technical authorities impose

- Can sell the program more easily, promising reduced technical risks by only modifying a successful design.

In this case the designer already has the same ship reference with the ship will be designed, so the design process can be faster and just add some modifications according to the owner requirements. The reference vessel used as a reference should be proven to have good performance such as stability and obstacles. From the main size of the sister ship can also be obtained the size main ship that will be designed. Modifying the ship's principal dimension should pay attention to the size ratio limits. The following main dimension of sister ships are shown in Table 1. From this existing data, input data for design the new folding Boat:

Table 1. Data of ONAK Canoe as Sister Ship's Folding Boat (ONAK)

\begin{tabular}{|l|l|}
\hline LOAM & $4.65 \mathrm{~m} ;$ \\
\hline Beam & $0.85 \mathrm{~m} ;$ \\
\hline Height & $0.25 \mathrm{~m} ;$ \\
\hline Construction & polymer polypropylene; \\
\hline Passanger & $3 ;$ \\
\hline
\end{tabular}


This data is used as an input in Bentley Maxsurf software, a software for creating initial hull design and assess stability of existing vessel more quickly [7] and the results of the new design as below:

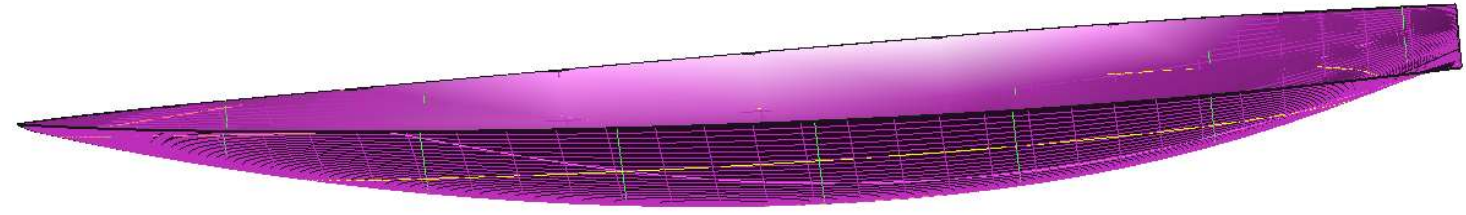

Figure 4. Perspective View of New Design Folding Boat

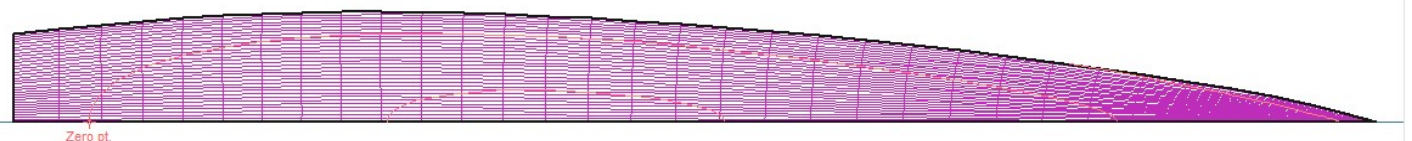

Figure 5. Half Breadth of New Design Folding Boat

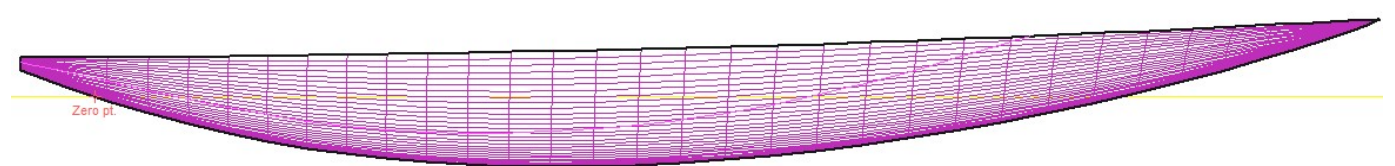

Figure 6. Sheer Plan of New Design Folding Boat

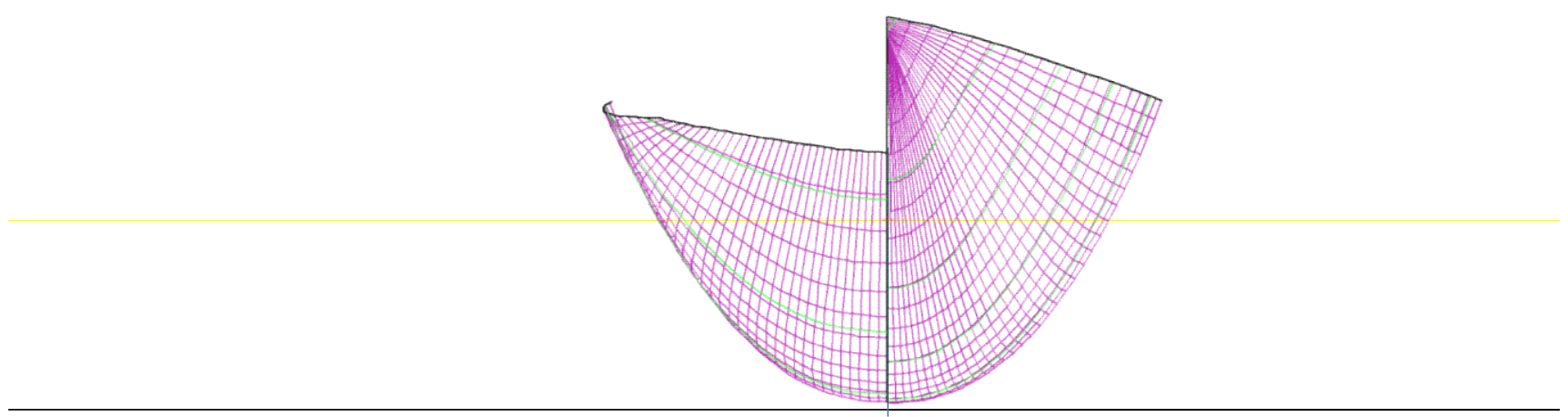

Figure 5. Body Plan of New Design Folding Boat

Table 2. Hydrostatic Calculation of Sister Ship's Folding Boat

\begin{tabular}{|l|l|r|l|}
\hline $\mathbf{1}$ & Displacement & $\mathbf{0 . 0 7 9 9}$ & Ton \\
\hline $\mathbf{2}$ & Volume (displaced) & 0.297 & $\mathrm{M}^{3}$ \\
\hline $\mathbf{3}$ & Draft Amidships & 0.285 & $\mathrm{M}$ \\
\hline $\mathbf{4}$ & Immersed depth & 0.28 & $\mathrm{M}$ \\
\hline $\mathbf{5}$ & WL Length & 4.144 & $\mathrm{M}$ \\
\hline $\mathbf{6}$ & Beam max extents on WL & 0.669 & $\mathrm{M}$ \\
\hline $\mathbf{7}$ & Wetted Area & 2.718 & $\mathrm{~m}^{2}$ \\
\hline $\mathbf{8}$ & Max sect. area & 0.127 & $\mathrm{~m}^{2}$ \\
\hline
\end{tabular}

From table 2, the principal dimension of folding boat is taken and this data will be used to check size ratio limit based on literature review.

$\begin{array}{ll}\text { Lo } & =5.487 \mathrm{~m} \\ \text { Ho } & =0.588 \mathrm{~m} \\ \text { Bo } & =0.870 \mathrm{~m} \\ \text { To } & =0.280 \mathrm{~m}\end{array}$ 
The constraints are the minimum or maximum determined based on field conditions, technical calculations, or requirements issued by both national and regulatory holders international. For the boat with length less than $24 \mathrm{~m}$, international or national regultory were not followed. The boundaries consist of some part such as limitation of principal dimension of ship, ratio of principal dimension of ship, limitation of ship capacity and limitations stability of the ship. Limitation of principal dimension are determined based on the comparison exsisting data that have been obtained. Ratio of principal dimension was obtained from the study literature that already exist today. Limitation of capacity determined based on the percentage of the ship displacement difference by the amount LWT and DWT in order to float according to Archimedes' law. While the limits stability is determined by the regulations issued by IMO A.749 (18) Chapter 3 and HSC Code 2000 Annex 7.

The constraints are as follows in Table 3. Limitation of prinsipal dimension is obtained from Principle of Naval Architecture Vol.I page.19, Ship Dsgn for Effciency \& Ecnmy-Schneekluth page.160 and Practical Ship Design page.71 about the requirements and ratio calculation for principal dimension

Table 3. Principal Dimension Ratio

\begin{tabular}{cccl}
\hline Ratio & Restriction & Value & Remark \\
\hline $\mathrm{Lo} / \mathrm{Bo}$ & $3.5<\mathrm{L} / \mathrm{B}<10$ & 6.307 & Accepted \\
$\mathrm{Bo} / \mathrm{To}$ & $1.8<\mathrm{B} / \mathrm{T}<5$ & 3.107 & Accepted \\
$\mathrm{Lo} / \mathrm{To}$ & $10<\mathrm{L} / \mathrm{T}<30$ & 19.596 & Accepted \\
$\mathrm{Bo} / \mathrm{Ho}$ & $1.47<\mathrm{B} / \mathrm{H}<2.38$ & 1.480 & Accepted \\
$\mathrm{Lo} / \mathrm{Ho}$ & $8.12<\mathrm{L} / \mathrm{H}<15.48$ & 9.332 & Accepted \\
$\mathrm{Lo} / 16$ & $\mathrm{Lo} / 16<\mathrm{Ho}$ & 0.343 & Accepted \\
$\mathrm{To} / \mathrm{Ho}$ & \pm 0.73 & 0.476 & Accepted \\
\hline
\end{tabular}

The value of the principal dimension comparison table is directions for naval architect to customize reasonable shapes and sizes and to avoid the formation of ships which deviates from habit. Values are loaded in principal dimension comparison list and coefficients form has been taken into account, both in terms of ship building theory calculation, material and the applicable and the applicable terms experience / development of ship that has been running for so long.

- Comparison of L / B

The length of ship L is especially influent on speed of the ship and the strength of the ship's length. Added L length to fixed displacement will reduce the ship resistance and ship strength, reduces motion ability of the ship (maneuver) and reduce the use of shipyard facilities. While reduction of $\mathrm{L}$ length in displacement still will make the ship body get bigger. A large L / B ratio is suitable for ships with high speed and have good room comparison, but the ship movement ability and stability were reduced. As for comparison L / B which will add little to the ability of stability, but the ship's resistance grew.

- Comparison of L / H

Especially affect the elongated strength ship. For big L / H cause the strength of the ship's longitudinal strength is reduced and vice versa for small $\mathrm{L} / \mathrm{H}$ value will be increase the strength of the ship's length.

- Comparison of B / T

The width of ship B mainly affects the high metacentra. Addition of width B on displacement, long and full of fixed ship will causing a high rise in MG metacentra. The addition of width $\mathrm{B}$ is generally intended to get additional room hull. But it can reduce usage dock facilities and shipyard. The B / T ratio has an effect on stability ship, the price of the B / T ratio is great the stability of the vessel becomes better while small $\mathrm{B} / \mathrm{T}$ price will reduce stability ship. For river ships price comparison B / T is taken very large, because of the price $\mathrm{T}$ is bounded by the depth of the river that is on generally already certain.

- Comparison of $\mathrm{H} / \mathrm{T}$

High deck $\mathrm{H}$ has an effect on high weight of ship, $\mathrm{KG}$, strength as well room ship. Added height of deck $\mathrm{H}$ will cause the increase in $\mathrm{KG}$ so high MG metacentra is reduced and longitudinal strength increases despite length of longitudinal stiffener fixed. $T$ draft has a 
special influence on Center of buoyancy (KB). The addition of $T$ is always avoided, because it can cause the ship capsize, reduce the number of harbors that can be visited and the use of dock facilities is reduced. Comparison of $\mathrm{H} / \mathrm{T}$ will primarily affect with reserve displacement. Large $\mathrm{H} / \mathrm{T}$ value can be found on passenger ships. Value $\mathrm{H}-\mathrm{T}$ called the free board, so the hull is the height of the deck surface from the water surface.

\section{Conclusion}

Principal dimension of folding boat are: $\mathrm{Lo}=5.487 \mathrm{~m}$; Ho $=0.588 \mathrm{~m}$; Bo $=0.870 \mathrm{~m}$; and To $=0.280$ $\mathrm{m}$. Using parental ship design approach with ONAK canoe as a sister ship and satisfy all of size ratio limit based on literature review.

\section{Acknowledgments}

This study is one of the researches funded by Kalimantan Institute of Technology Year 2017.

\section{References}

Robert G. Keane, Jr., Ship Design USA, Inc., CAPT Barry F. Tibbitts, USN (Ret). The Fallacy Of Using A Parent Design:'The Desin Is Mature".

Evans, J. H. (1959). Basic Design Concepts. American Society of Naval, 671-674.

Manual Ventura. Ship Design I. Instituto Superior Ticnico.

Watson, D.G.M (1997). Practical Ship Design. Elsevier Ocean Engineering Book Series Volume 1.

Taggart, Robert. (1980). Ship Design and Construction. New York: The Society of Naval Architects and Marine Engineers.

onakcanoes.com/

Onak. "Origami foldable canoe". 15 December 2017.https://onakcanoes.com/canoe

Bentley. "Vessel performance". 12 December 2017. https://www.bentley.com/en/products/brands/maxsurf 